\title{
ANALYSIS OF THE GRASS (Poaceae L.) POLLEN SEASONS IN WROCŁAW, 2003-2010
}

\author{
Małgorzata Malkiewicz, Kamilla Klaczak \\ Department of Paleobotany, Institute of Geological Sciences, Wrocław University, \\ Cybulskiego 34, 50-205 Wrocław, Poland \\ e-mail: malgorzata.malkiewicz@ing.uni.wroc.pl
}

Received: 20.08.2011

\begin{abstract}
The aim of the study was to analyse the grass pollen season dynamics in Wrocław in 2003-2010. The studies were carried out using volumetric method (Burkard trap). Special attentions was paid to differences in pollen season duration and patterns. The pollen season started on average on the $130^{\text {th }}$ day of the year ( \pm 10 days) and ended on the $240^{\text {th }}( \pm 11$ days $)$. Peak of pollen seasons occurred between $156^{\text {th }}$ and $185^{\text {th }}$ day of the year. The mean of SPI value was $2805( \pm 380)$. On average, 18 days ( \pm 4 days) with a grass pollen concentration of more than 50 grains $\times \mathrm{m}^{-3}$, and 2 days ( \pm 1 day) with concentration of more than 120 grains $\times \mathrm{m}^{-3}$ were recorded during the seasons analysed. Three types of pollen seasons were distinguished on the basis of cluster analysis (the non-hierarchical method of multifeature clustering - the k-means method).
\end{abstract}

Key words: pollen seasons, grass pollen, k-means method, Wrocław

\section{INTRODUCTION}

The Poaceae family is one of the most abundant families among different species of the Polish flora. It comprises over 180 species, out of which more than 30 species are of foreign origin ( $\mathrm{S} \mathrm{z}$ a f e $\mathrm{r}$ et al. 1988). As a result of the simple construction of grasses and their uncomplicated reproduction mechanisms, they are well adapted to survive even under extremely adverse conditions and that is why they are described as plants that have achieved evolutionary success (M i zi a n ty, 1995; Frey, 2003). Moreover, grasses are a plant family of great economic importance, in particular as food for animals and humans. On the other hand, grass pollen allergens are the greatest threat to allergy sufferers in Central and Western Europe, being the most frequent cause of seasonal allergic rhinoconjunctivitis and pollen asthma (Berger, 2003; D 'A m a t o et al. 2007). Across Europe, grasses have the longest-lasting pollen season - from May till the end of September. In Poland the main period of grass pollen shed is in the second half of May, in June and July (Ligęziński and Rapiejko, 1994). During the grass flowering period, more than $90 \%$ of people allergic to grass pollen suffer from allergic complaints (O b t u ł o w i c z et al. 1991). The first clinical symptoms usually occur after a concentration of ca. 20 grass pollen grains in $1 \mathrm{~m}^{3}$ of air has been reached (R a p i j k o et al. 2004), whereas pollinosis occurs in all allergy sufferers at a concentration of more than 50 grains $\times \mathrm{m}^{-3}$ of air (R a p i e j k o et al. 2007).

This paper presents the results of analysis of the grass pollen seasons in Wrocław in the period 20032010. In analysing the results, special attention was paid to variations in pollen concentrations as well as to differences in pollen season duration and patterns over an 8-year study period. Furthermore, several types of pollen seasons were distinguished on the basis of the differences in pollen concentration curves.

\section{MATERIALS AND METHODS}

The present study was conducted in Wrocław in the period 2003-2010. This city is located in south-western Poland, at the foreland of the Sudety Mountains and in the centre of the Silesian Lowland (K o n $\mathrm{dracki}, 2001)$. Wrocław is strongly affected by the oceanic climate. Winters are mild and short, while the springs start early. The growing season lasts 225 days (Ko s i b a, 1948; D u b i c ki et al. 2002).

The investigations were carried out using the volumetric method. A Burkard trap (borrowed from the Warsaw-based Centre for Research on Environmental 
Allergens) was placed in the city centre, on the roof of the Institute of Geological Sciences of the University of Wrocław $\left(51^{\circ} 06^{\prime} \mathrm{N}, 17^{\circ} 01^{\prime} \mathrm{E}\right)$, at a height of about $30 \mathrm{~m}$ above ground level. In the immediate vicinity of the sampling site, there are a dense urban built-up area and scanty patches of greenery. From the south, the building is surrounded by an alley of plane trees, while several horse-chestnut trees and small birches grow to the north of the building.

The start and end dates, duration, maximum daily concentrations and the Seasonal Pollen Index (SPI) were used to characterize the pollen seasons (Table 1). The $98 \%$ method was used to determine the start and end dates of the pollen seasons (E mberlin et al. 1993). To classify the pollen seasons, cluster analysis was employed, including the non-hierarchical method of multi-feature clustering - the k-means method using Statistica 6 software.

\section{RESULTS}

In the years under study, the grass pollen seasons started in May, except at 2007, when the pollen season began already on the 20 of April. They generally lasted till 230-240 day of the year (2003 and 20072010), and only during the period 2004-2006 until around 260 day of the year.
Duration of the pollen seasons ranged from 87 days in 2003 to 166 days in 2005 . The lowest maximum daily concentration occurred in 2008 (126 grains $\times \mathrm{m}^{-3}$ ), while the highest one in the years 2005 and 2010, reaching respectively 317 grains $\times \mathrm{m}^{-3}$ and 250 grains $\times \mathrm{m}^{-3}$. Positive correlation $(\mathrm{r}=0.58)$ were found between season duration and maximum daily concentration. In the years under question, peak of pollen seasons occurred between day 156 (2008) and day 185 of the year (2010) (Table 1).

On average, 18 days with a grass pollen concentration of more than 50 grains $\times \mathrm{m}^{-3}$, which causes allergic symptoms in most allergy sufferers, were recorded during the seasons analysed. The highest number of such days was in 2007 (25 days) and the lowest one in 2009 (11 days). Moreover, a concentration of more than 120 grains $\times \mathrm{m}^{-3}$, which causes dyspnoea in allergic people, occurred in all the years analysed. These were 2 days on average, and even 4-5 days in the 2005 and 2010.

The lowest seasonal pollen index (SPI) for grass pollen was recorded in 2003 and 2009, while the highest one in 2005, 2007, and 2010. SPI values were at a level proportionate to maximum daily grass pollen concentrations. The coefficients of the correlation $(r)$ between annual total and year number is 0.54 (Table 1).

Table 1.

Characteristics of Poaceae pollen seasons in Wrocław in 2003-2010.

\begin{tabular}{|c|c|c|c|c|c|c|c|}
\hline \multirow{2}{*}{ Year } & \multicolumn{3}{|c|}{ Season } & \multirow{2}{*}{$\begin{array}{c}\text { Peak concentrations } \\
\left(\text { pollen grains } \times \mathrm{m}^{-3}\right)\end{array}$} & \multirow{2}{*}{$\begin{array}{l}\text { Date of peak } \\
\text { concentration* }\end{array}$} & \multirow{2}{*}{ SPI } & \multirow{2}{*}{$\geq 50 * *$} \\
\hline & Start* & End* & Duration (days) & & & & \\
\hline 2003 & 17-05 (137) & $11-08$ (223) & 87 & 134 & $10-06(161)$ & 2193 & 16 \\
\hline 2004 & $12-05(133)$ & 07-09 (252) & 120 & 147 & $27-06(180)$ & 3036 & 19 \\
\hline 2005 & $14-05(134)$ & 06-09 (249) & 166 & 317 & $27-06$ (178) & 3158 & 22 \\
\hline 2006 & $15-05(135)$ & $14-09$ (257) & 123 & 166 & 01-07 (182) & 2706 & 15 \\
\hline 2007 & 20-04 (110) & $29-08(241)$ & 132 & 171 & $20-06(171)$ & 3115 & 25 \\
\hline 2008 & 05-05 (126) & $16-08(230)$ & 105 & 126 & 03-06 (156) & 2787 & 21 \\
\hline 2009 & 02-05 (122) & 25-08 (237) & 116 & 174 & 03-07 (184) & 2233 & 11 \\
\hline 2010 & 26-05 (146) & 25-08 (237) & 92 & 250 & 04-07 (185) & 3213 & 19 \\
\hline Mean & $10-05(130,4)$ & $28-08(240,8)$ & 117,6 & 185,6 & $23-06(174,6)$ & 2805,1 & 18,5 \\
\hline Standard deviation & 10,2 & 10,7 & 23,3 & 61,1 & 10,2 & 379,5 & 4,1 \\
\hline Coefficient of variation & 3,6 & 3,8 & 8,2 & 21,6 & 3,6 & 134,2 & 1,5 \\
\hline Max & 26-05 (146) & $14-09(257)$ & 166 & 317 & 04-07 (185) & 3213 & 25 \\
\hline Min & 20-04 (110) & $11-08(223)$ & 87 & 126 & 03-06 (156) & 2193 & 11 \\
\hline \multicolumn{4}{|c|}{ Season parameters } & \multicolumn{4}{|c|}{ Correlation coefficient (r) } \\
\hline \multicolumn{4}{|c|}{ Peak concentration and SPI } & \multicolumn{4}{|c|}{0.54} \\
\hline \multicolumn{4}{|c|}{ Peak concentration and season duration } & \multicolumn{4}{|c|}{0.58} \\
\hline \multicolumn{4}{|c|}{ Seasons start and duration } & \multicolumn{4}{|c|}{-0.33} \\
\hline
\end{tabular}


A comparison of the curves illustrating the dynamics of the grass pollen seasons allowed one to conclude that they differed between years. An attempt was therefore made to classify the patterns of the pollen seasons and to distinguish their types. For this reason cluster analysis by the k-means method was employed. Three types of grass pollen seasons were distinguished on the basis of claster analysis. Type A includes the seasons 2005 and 2010 (Fig. 2). It is marked by high maximum daily concentrations (above 200 grains $\times \mathrm{m}^{-3}$ ), which are recorded around the 40 day of the season. Moreover, maximum pollen shed is three-peaked ('three-peaked' means there is shortly high concentration and than suddenly drops to low values). The largest number of pollen seasons was classified as type B (the years 2003, 2004, 2006 and 2008) (Fig. 3). Relatively low maximum daily concentrations (between 100 and 150 grains $\times \mathrm{m}^{-3}$ ), which occur soon after the beginning of the season, are characteristic of this type. In addition, there occurs a long continuous period of pollen shed with low concentrations. Type C comprises the years 2007 and 2009 (Fig. 4). It is characterized by low maximum concentrations, similarly to type B. Besides, peak pollen shed occurs the latest, around day 62 of the season. Long post-peak periods were also found for all types of pollen seasons.

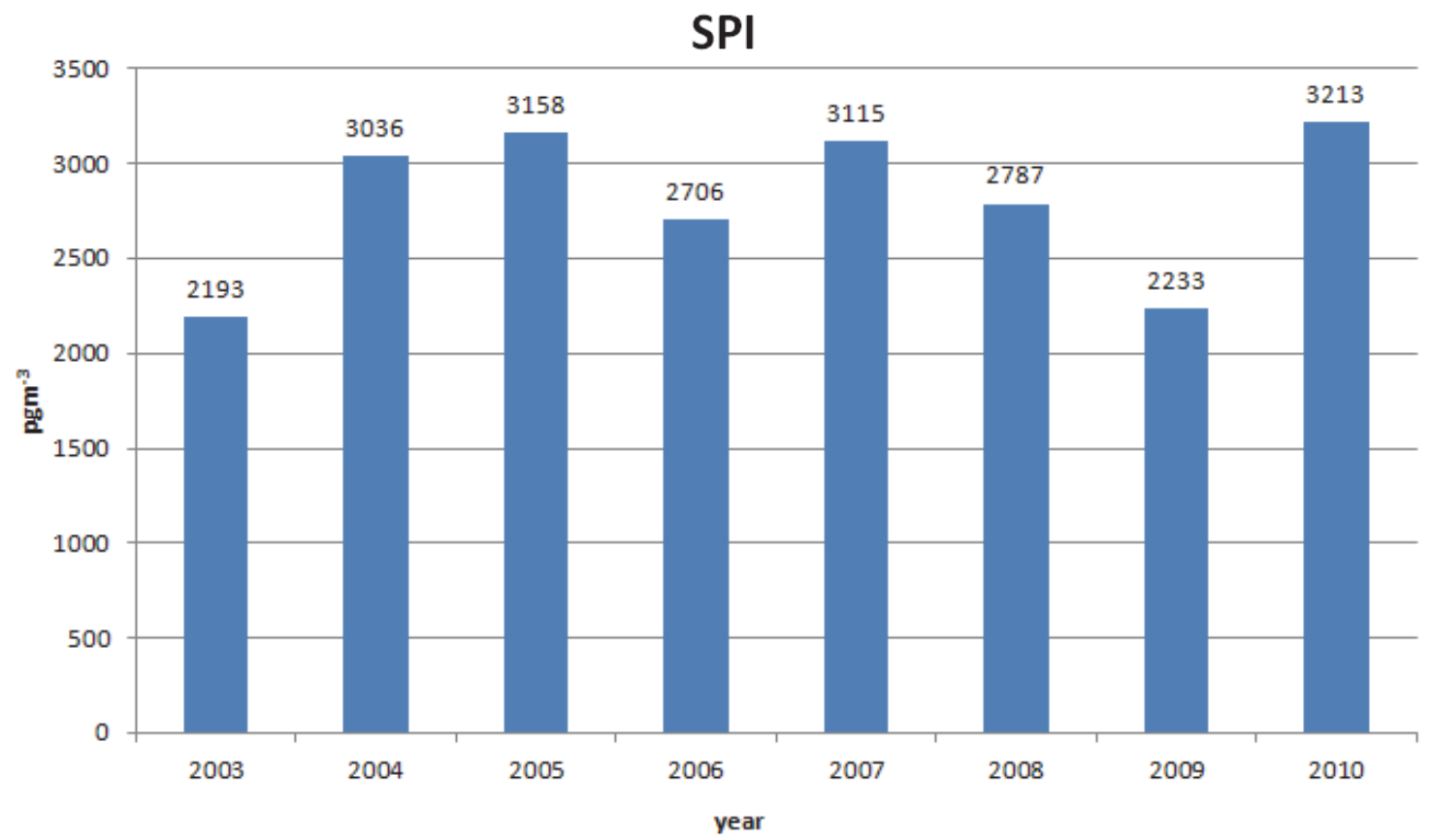

Fig. 1. Seasonal pollen index of Poaceae pollen in Wrocław in 2003-2010.

\section{Type A}

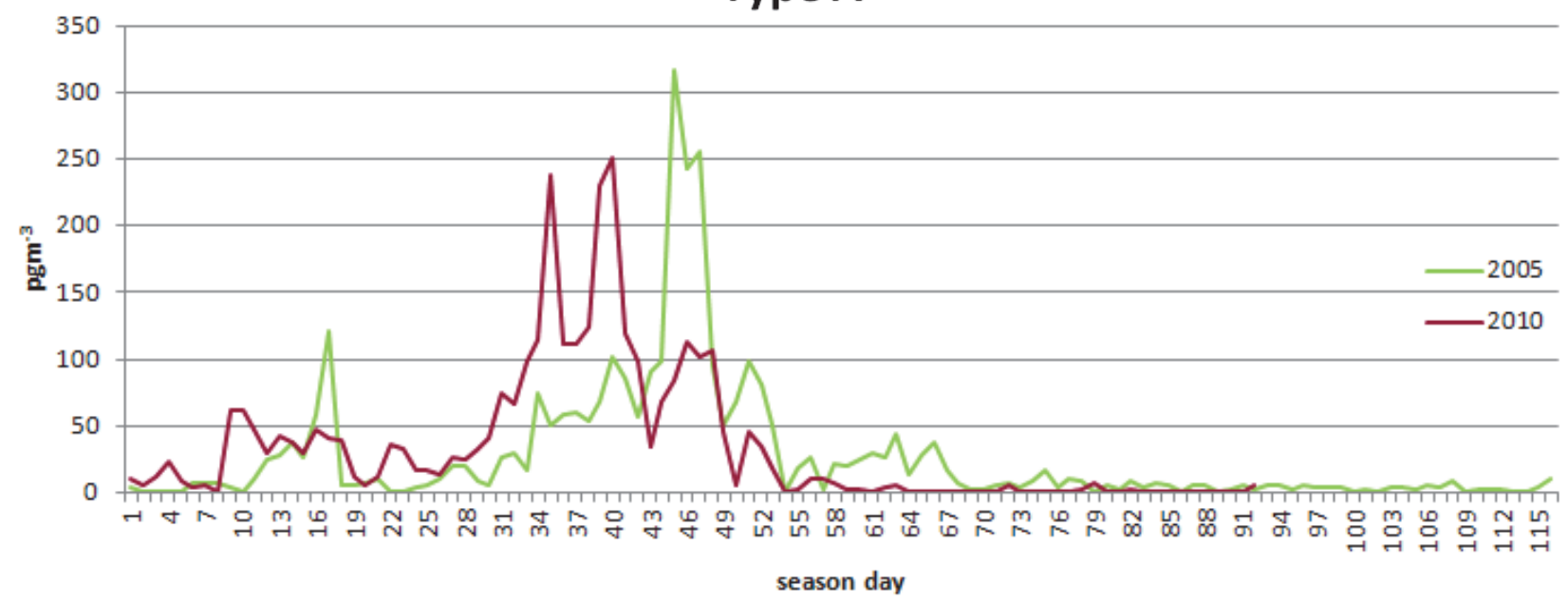

Fig. 2. Poaceae pollen season in Wrocław - type A. 


\section{Type B}

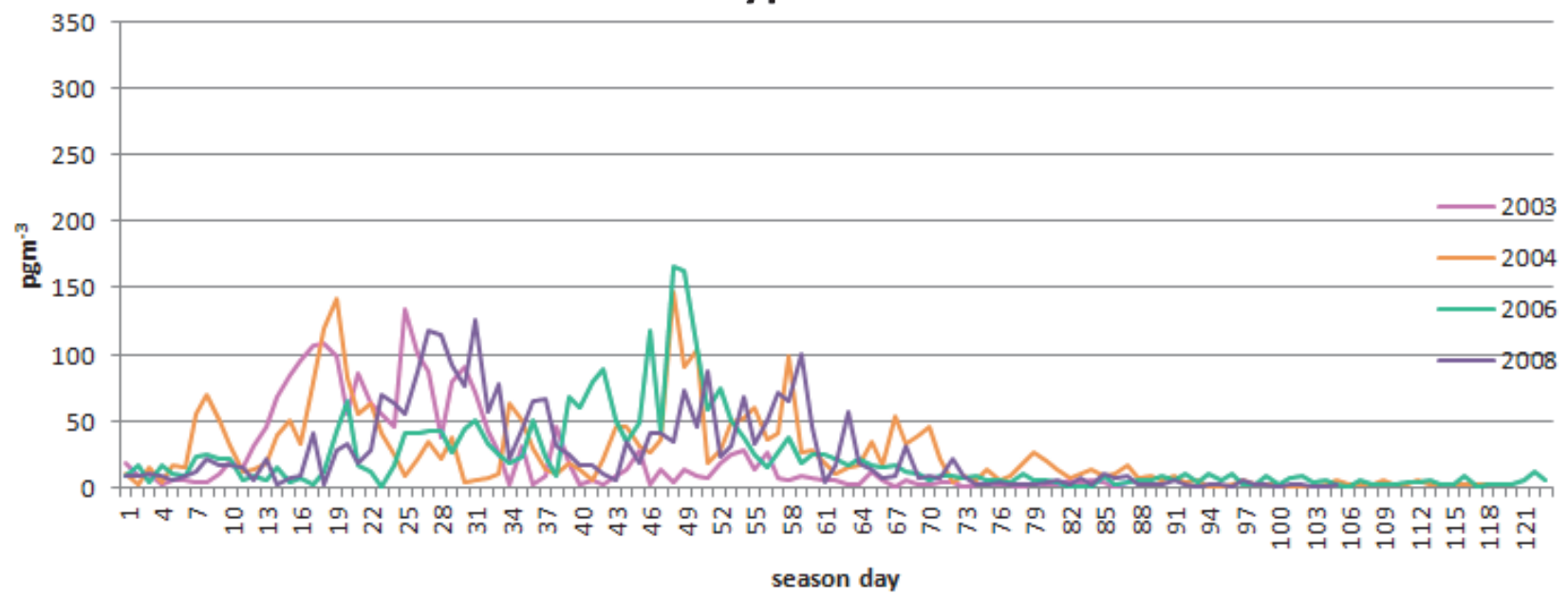

Fig. 3. Poaceae pollen season in Wrocław - type B.

\section{Type C}

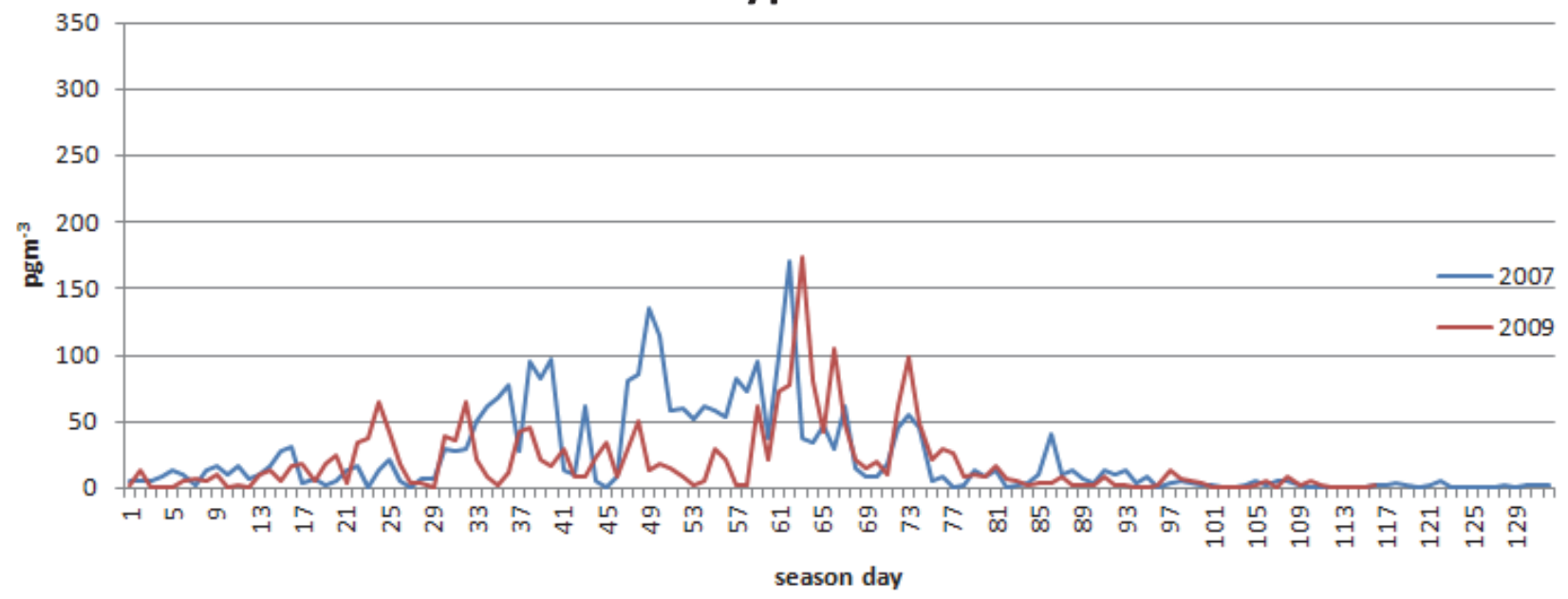

Fig. 4. Poaceae pollen season in Wrocław - type C.

\section{DISCUSSION}

The start date of the grass pollen season differs in various parts of Europe (E m berlin et al. 1993; J a to et al. 2009). In Central and Northern Europe, the grass pollen season usually starts at the beginning of May, while in the Mediterranean region it begins in April (E mberlin et al. 2000; Le on-Ruiz et al. 2011; S a b a ri e g o et al. 2011). But all over Europe the highest pollen concentrations are noted in June (D'A m a to et al. 2007; Chło pek, 2007; M y s zkow ska, 2010; M y s zkow ska et al. 2011; Puc, 2011).

In Wrocław the grass pollen seasons usually began between the 122 and 137 day of the year (3 May 17 May). However, there were years (2007 and 2010) in which the onset of the pollen season was on the
110 day of the year (20 April) and on 146 day (26 May). Similar fluctuations in the onset of grass pollen seasons were noted in other cities of Poland (W e ryszko-Chmielewska, 2006; Myszkow$\mathrm{ska}, 2010)$. The difference in the start of the grass pollen season between the countries of Northern and Southern Europe can be even 2.5 months (E m b e r 1 i n et al. 2000). Correlations between the start of the pollen seasons and their duration were also found. Generally, in the years when the seasons started late, their length was shortened. The coefficients of the correlation (r) between seasons start and duration is - 0.33 (Table 1). In 2003 the pollen season ended already after 87 days (11 August) and in 2010 after 92 days. The same correlation was found for hazel (Piotrowicz and Myszkowska, 2006). Myszkowska (2010) believes that duration of particular pollen seasons are 
affected by air temperature, rainfall, relative humidity, cloudiness and relative sunshine.

An increasing trend in the seasonal pollen index (SPI) was observed in polish cities ( $\mathrm{R}$ a p i e j k o et al. 2009, 2011; M y s zk ow s ka, 2010). Many authors have described an increasing trend in annual pollen totals, associated more with an increase in $\mathrm{CO}_{2}$ concentration in the cities (Fre i, 1998; B e g g s, 2004). In Wrocław there is no sufficient data (pollen concentration is monitored only for 8 years) to define trend in SPI. However, the highest daily concentrations were recorded in the years, in which annual pollen counts were the highest or very high. A correlation $(r=0.54)$ were found between the seasonal pollen index (SPI) and maximum daily concentrations (Table 1 ). In the last two years, a similar correlation has been found in Szczecin, Bydgoszcz, and Warsaw (R a p i e j k o et al. 2009, 2011). The same correlation has been observed for oak by Dąb row s k a - Z a part (2010).

Grass pollen is considered to be one of the most important allergens among the pollen of herbaceous plants. The study conducted in Wrocław in the period 2003-2010 showed that it reached high and very high concentrations in this city. R a pi ejko and Lipiec (2005) calculated that the number of days with a grass pollen concentration at which clinical symptoms appear in all allergic people was 27 for Poland. In 2007 in Wrocław, the number of days with a concentration of more than 50 grains $\times \mathrm{m}^{-3}$ of air was 25 . It was almost $1 / 5$ of the pollen season duration. The same number of days for Rome (25 days), and it was only slightly higher for Paris (29 days) was found (R a p i e j k o and Lipiec, 2005).

The significant differences in the patterns of the grass pollen seasons allowed us to be classified using an objective method of multi-feature clustering - the k-means method. For Wrocław, three main types of grass pollen seasons were obtained and they were designated as A, B and C. Attempts to classify pollen seasons are known from the existing literature. Nevertheless, grasses have never been the subject of research. Myszkowska and Piotrowicz (2009) distinguished 2 main pollen season types for birch, while Dąbrowska-Zapart (2010) made a classification of oak pollen seasons.

In the distinguished types of grass pollen seasons in Wrocław, the pre-peak period drags attention. Type A, lasts about 33 days and daily concentrations of grass pollen are quite high (ca. 50 grains $\times \mathrm{m}^{-3}$ of air). The pollen season is slightly longer in type $\mathrm{C}$ (about 45 days), but daily pollen concentrations are lower. The shortest pre-peak period seems to be in type B (about 15 days), though daily concentrations are similarly low as in type C. A second interesting feature of all the pollen seasons under study is their long post-peak period, characterized by low concentrations of pollen grains. Among the peak sections, the peak section in type B seems to be particularly long and diverse. It is much spread in time (from around 13 day to 60 day of the season). For the years 2003, 2004 and 2008, maximum concentrations occur between 15 day and 30 day of the season, whereas for the year 2006 around 45-49 day of the season. Furthermore, the peaks with highest concentrations are separated by periods, when daily concentrations fall to zero. The peak section in type A appears to be shortest and most clear. It is very compact, since its duration is about 16 days. A second feature distinguishing type $\mathrm{A}$ is the fact that the peaks with maximum concentrations are not separated by periods when daily concentrations drop to low values.

A comparison of particular types of pollen seasons allowed us to conclude that type $\mathrm{B}$ comprised the largest number of the studied seasons (50\%) and it may prove to be the dominant pattern for the grass pollen season in Wrocław. The other types of pollen seasons showed higher dispersion, as they comprised only two pollen seasons each. An 8-year period is probably too short to identify all types found in nature.

\section{CONCLUSIONS}

1. In Wrocław the grass pollen seasons usually began between 122 and 137 days of the year (2 May 17 May).

2. The length of the grass pollen seasons was shortened in the years, in which the seasons started late.

3. An increasing trend in the seasonal pollen index (SPI) as well as a correlation between the SPI and maximum daily concentrations there were observed.

4. In the case of grasses, type B proved to be the most characteristic pattern for airborne pollen concentrations (the years 2003, 2004, 2006, and 2008). The other two types (A and C) showed high dispersion (they comprised only 2 pollen seasons each).

5. Type B may prove to be the dominant pattern for the grass pollen season in Wrocław $(50 \%$ of the pollen seasons under study).

6. Long post-peak periods were found for all types of pollen seasons.

\section{REFERENCES}

B egg s P.J., 2004. Impacts of climate change on aeroallergens: past and future. Clin Exp Allergy, 34: 1507-1513.

Berger W.E., 2003. Overview of allergic rhinitis. Ann. Allergy Asthma Immunol. 3: 7-12. 
D`Amato D., Cecchi L., Bonini S., Nunes C., Annesi-Maesano I., Behrendt H., Liccardi G., Popov T., van Cauwenberge P., 2007. Allergenic pollen and pollen allergy in Europe. Allergy, 62 (9): 976-990.

Dąbrowska-Zapart K., 2010. Sezony pyłkowe dębu w Sosnowcu w latach 1997-2007./ Oak pollen season in Sosnowiec in 1997-2007. Alergoprofil, 6 (2): 38-45. (in Polish)

Dubicki A., Dubicka M., Szymanowski M., 2002. Klimat Wrocławia. [In:] Środowisko Wrocławia. Informator 2002. K. Smolnicki, M. Szykasiuk (eds). Dolnośląska Fundacja Ekorozwoju, Wrocław: 9-25. (in Polish)

Chłope k K., 2007. Grass pollen (Poaceae) in the air of Sosnowiec (Poland). Acta Agrobot. 60 (2): 79-86

Emberlin J., Savage M., Jones S., 1993. Annual variations in grass pollen seasons in London 19611990: trends and forecast models. Clin. Exp. Allergy, 23: 911-918.

Emberlin J., Jaeger S., Dominguez-Vilches E., GalanSoldevilla C., Hodal L., Mandrioli P., Rantio-Lehtimaki A., Savage M., Spieksma F. Th., Bartlett C., 2000. Temporal and geographical variations in grass pollen seasons in areas of western Europe: an analysis of season dates at sites of the European pollen information system. Aerobiologia, 16: 373-379.

Frei T., 1998. The effects of climate change in Switzerland 1969-1996 on air borne pollen quantities from hazel, birch and grass. Grana, 37: 172-179.

Frey L., 2003. Problems of grass biology. Szafer Institute of Botany, Polish Academy of Sciences, Kraków.

Jato V., Rodriguez-Rajo F.J., Saijo M.C., A ira M., 2009. Poaceae pollen In Galicia (N. W. Spain): characterization and recent trends in atmospheric pollen season. Int. J. Biometeorol. 53: 333-344.

Mizianty M., 1995. Trawy - grupa roślin, która odniosła ewolucyjny sukces./ Grasses - group of plants which achieved evolutional success. Wiadomości Botaniczne, 39 (1/2): 59-70. (in Polish)

Ko n d ra ck i J ., 2001. Geografia regionalna Polski. Państwowe Wydawnictwo Naukowe, Warszawa. (in Polish)

Ko sib a A., 1948. Klimat Ziem Śląskich. Wyd. Inst. Śląsk., Wrocław-Katowice. (in Polish)

Leon-Ruiz E., Alcazar P., Dominguez-Vilches E., Galan C., 2011. Study of Poaceae phenology in a Mediterranean cli mate. Which species contribute most to air borne pollen counts? Aerobiologia, 27: 37-50

Ligęziński A., Rapiejko P., 1994. Koncentracja pyłku roślin w atmosferze Polski. /Plant pollen concentrations in the atmosphere of Poland. Pneumonol. Alergol. Pol. 62: 347-351. (in Polish)

Myszkowska D., 2010. The grass pollen season dynamics in relations to the meteorogical conditions in Cracow, Southern Poland, 1991-2008. Acta Agrobot. 63 (2): 85-96
Myszkowska D., Piotrowicz K., 2009. Birch (Betula L.) pollen seasons in Cracow in 1991-2008 in relation to meteorological coditions. Acta Agrobot. 62 (2): 67-75.

Myszkowska D., Jenner B., Stępalska D., Czarnobilska E., 2011. The pollen season Dynamics and the relationship among some season parameters (start, end, annual total, season phases) in Kraków, Poland, 1991-2008. Aerobiologia, 27: 229-238

Obtułowicz K., Szczepanek K., Radwan J., Grzywacz M., Adamus K., Szczeklik A., 1991. Correlation between airborne pollen incidence, skin trick tests and serum immunoglobulin in allergic people in Cracow, Poland. Grana, 30: 136-141.

Piotrowicz K., Myszkowska D., 2006. Początek sezonów pyłkowych leszczyny na tle zmienności klimatu Krakowa./ The start data, end and duration of the hazel pollen seasons on the background of climate changes in Krakow. Alergologia Immunologia, 3 (3-4): 86-89. (in Polish)

Puc M., 2011. Threat of allergenic airborne grass pollen in Szczecin, NW Poland: the dynamics of pollen seasons, effect of meteorological variables and air pollution. Aerobiologia, 27: 191-202

Rapiejko P., Lipiec A., 2005. Pyłek traw - aerobiologia, charakterystyka alergenów i aspekt kliniczny./ The Grass pollen - aerobiology, allergens' characteristics and clinical aspekt. Alergoprofil, 2 (2): 40-49. (in Polish)

Rapiejko P., Lipiec A., Wojdas A., Jurkiewicz D., 2004. Threshold pollen concentration necessary to evoke allergic symptoms. Int. Rev. Allergol. Clin. 10 (3): 91-94.

Rapiejko P., Stankiewicz W., Szczygielski K., Jurkiewicz D., 2007. Progowe stężenie pyłku roślin niezbędne do wywołania objawów alergicznych. / Threshold pollen count necessary to evoke allergic symptoms. Otolaryngol. Pol. 61 (4): 591-594. (in Polish)

Rapiejko P., Buczyłko K., Wagner A., Puc M., Malkiewicz M., Chłopek K., ZielnikJurkiewicz B., Myszkowska D., StasiakBarmuda A., Wawrzyniak Z., Stankiewicz W., 2009. Pyłek traw w powietrzu wybranych miast Polski w 2009 roku. / Grass pollen in the air of selected Polish cities in 2009. Alergoprofil, 5 ( 3): 3640. (in Polish)

Rapiejko P., Lipiec A., Weryszko-Chmielewska E., Piotrowska K., Malkiewicz M., Puc M., Dżaman K., Szczygielski K., Rapiejko A., Wawrzyniak Z., 2011. Analiza stężenia pyłku traw w Polsce w 2010 roku. / The analysis of Grasse pollen Mount in Poland in 2010. Alergoprofil, 7 (1): 36-39. (in Polish)

Sabariego S., Perez-Badia R., Bouso V., Gutierrez M., 2011. Poaceae pollen in the atmosphere of Aranjuez, Madrid and Toledo (central Spain). Aerobiologia, 27: 221-228 
Szafer W., Kulczyński S., Pawłowski B., 1988. Rośliny Polskie. Państwowe Wydawnictwo Naukowe, Warszawa. (in Polish)

Weryszko-Chmielewska E., 2006. Pyłek roślin w aeroplanktonie różnych regionów Polski. Wyd. Katedra i Zakład Farmakognozji Wydziału Farmaceutycznego AM, Lublin. (in Polish)

\section{Analiza sezonów pyłkowych traw (Poaceae L.) we Wrocławiu w latach 2003-2010}

\section{Streszczenie}

Celem pracy było porównanie dynamiki sezonów pyłkowych traw (Poaceae L.) we Wrocławiu w latach 2003-2010 oraz wyróżnienie typów sezonów pyłkowych na podstawie różnic w przebiegu krzywych koncentracji ziaren pyłku.

We Wrocławiu sezony pyłkowe traw zaczynały się zazwyczaj pomiędzy 122 a 137 dniem roku (2.0517.05). Stwierdzono również relacje między początkiem sezonów pyłkowych traw a ich długością. Zazwyczaj w latach, których sezony zaczynały się późno, długość ich ulegała skróceniu.

Zaobserwowano dla Wrocławia zależność między SPI a wartościami maksymalnymi stężeń dobowych. Największe stężenia dobowe notowano w latach, w których roczne sumy ziaren pyłku były największe lub bardzo wysokie. Stwierdzono również ujemną korelację między początkiem sezonu a czasem jego trwania (Tab. 2).

Znaczne różnice w przebiegu sezonów pyłkowych traw pozwoliły na klasyfikację ich za pomocą obiektywnej metody grupowania obiektów wielocechowych - k-średnich. Dla Wrocławia otrzymano trzy główne typy sezonów pyłkowych traw, oznaczone jako A, B i C. Typ A obejmuje lata 2005 i 2010. Wyróżnia się on wysokimi maksymalnymi stężeniami dobowymi (powyżej 200 ziaren $/ \mathrm{m}^{3}$ ), które notowane są około 40 dnia sezonu. Ponadto maksimum pylenia jest trzyszczytowe. Do typu B zostało zakwalifikowanych najwięcej sezonów pyłkowych (lata 2003, 2004, 2006 i 2008). Charakterystyczne dla tego typu są stosunkowo niskie maksymalne stężenia dobowe (między 100 a 150 ziaren/m³), które występują niedługo po rozpoczęciu sezonu. Ponadto występuje długi okres zwartego pylenia o niskich stężeniach. Typ C obejmuje lata 2007 i 2009. Charakteryzuje się on niskimi maksymalnymi stężeniami, podobnie jak w typie B. Ponadto szczyt pylenia występuje najpóźniej, około 62 dnia sezonu. Dla wszystkich typów sezonów pyłkowych stwierdzono także długie okresy poszczytowe. Porównanie poszczególnych typów dynamiki sezonów pyłkowych pozwoliło stwierdzić, że typ B skupia najwięcej badanych sezonów (50\%) i być może to właśnie on okaże się dominującym wzorem sezonu pyłkowego traw dla Wrocławia. 
